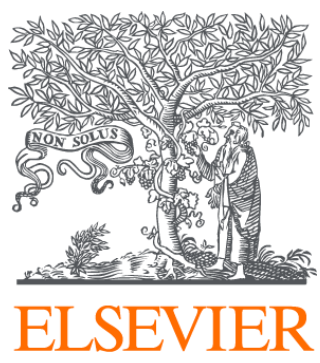

Since January 2020 Elsevier has created a COVID-19 resource centre with free information in English and Mandarin on the novel coronavirus COVID-

19. The COVID-19 resource centre is hosted on Elsevier Connect, the company's public news and information website.

Elsevier hereby grants permission to make all its COVID-19-related research that is available on the COVID-19 resource centre - including this research content - immediately available in PubMed Central and other publicly funded repositories, such as the WHO COVID database with rights for unrestricted research re-use and analyses in any form or by any means with acknowledgement of the original source. These permissions are granted for free by Elsevier for as long as the COVID-19 resource centre remains active. 
up the separation between the ISS and the object, and shorten the time the object remains in orbit before burning up.

The proposal comes as Russian cosmonaut Mikhail Tyurin prepares for a space walk on 22 November during which he will drive a golf ball from the ISS in a stunt for a golf company probably achieving the longest drive in history. NASA found that there was no threat of the 3-gram golf ball hitting the station either at the time of the swing or on a later orbit - it will quickly hit the atmosphere and burn up.

\section{WHO's boss}

IF THE best lessons are learned the hard way, Margaret Chan, who was confirmed as the WHO's new director general on 9 November, should be a star pupil. As director of health for Hong Kong, she was heavily criticised for her slow response to the 2003 outbreak of severe acute respiratory syndrome (SARS) in the region.

To her credit, her record on bird flu is more positive: in 1997 she recommended the slaughter of all poultry in Hong Kong to stop the spread of the $\mathrm{H}_{5} \mathrm{~N} 1$ virus and presided over the successful exclusion of the virus in poultry.

Supporters note that her experience with SARS might make her less likely to soft-pedal any similar information emerging from China, the potential epicentre of flu evolution. As a Chinese citizen she may also be

\section{"Chan's experience with SARS might make her less likely to soft-pedal on bird flu"}

more likely to establish good relations with China.

Chan replaces South Korea's Jong-wook Lee, who died suddenly in May. Besides flu, Chan will have to deal with AIDS, tuberculosis, malaria, the tricky endgame of polio eradication and perennial questions on how to promote healthcare and distribute medicines in poor countries.

\section{Abortion ban out}

SOUTH Dakotans last week voted to overturn a law banning almost all abortions in the state - but the issue is unlikely to go away.

The South Dakota law would have banned all abortions except when a woman's life was in danger, and was to take effect in July, until a pro-choice campaign forced the issue to a public ballot on 7 November.

The result, in which 56 per cent of people voted to repeal the law, may make other states think twice about introducing such draconian restrictions, says Jan Nicolay, of the South Dakota Campaign for Healthy Families in Sioux Falls.

\section{PROTECTION THAT ISN'T}

In an example of doublethink worthy of George Orwell, many so-called "marine protected areas" permit some exploitation of their marine resources. Their food webs are so complex, however, that even a little exploitation may be too much.

A quarter of Europe's red knots have died since 1998 because one of Europe's supposedly protected coasts, in a word, wasn't. The migrant seabirds stop off at intertidal mudflats, including the Wadden Sea off the Netherlands, to refuel on shellfish. The problem is that until 2004 two dozen cockle boats were allowed to dredge the Wadden too.

The boats didn't make much money. They did, however, make the mud coarser and so worse for cockles, whose meat-to-shell ratio fell 11 per cent per

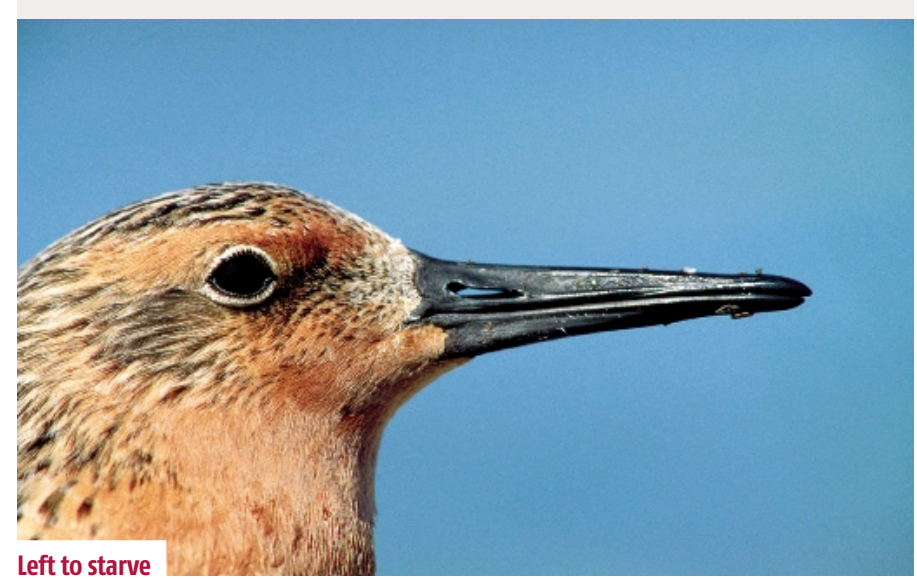
We have shown that does not exist
“The law would have banned all abortions except when a woman's life was in danger"

"We felt a responsibility to deter other states," she says.

Anti-abortion campaigners have not given up, however. Some believe that voters may accept a law that allows abortion in special circumstances only: in cases of rape or incest, for instance. Such abortions would have been illegal under the rejected law. Others are talking about introducing laws that would require pregnant women to look at ultrasound scans of their fetuses before aborting them.

year for five years, says Jan van Gils of the Royal Netherlands Institute for Sea Research in Texel. The scrawny cockles did not supply enough food for the red knots, whose numbers fell by 80 per cent, enough to account for the decline of knots across Europe (Public Library of Science Biology, vol 4(12), e376).

Many similar seas may suffer too, says van Gils, as "protection" often means nothing more than simplistic regulation of fisheries. "The idea is to exploit resources in a sustainable way. for the Dutch Wadden Sea."

The cockles have failed to recover since dredging ended, van Gils says, as the intertidal mud remains coarse. "Dredging didn't even provide significant economic benefits," he adds.

\section{Storm the size of a planet}

NASA's Cassini spacecraft has spotted a gigantic storm two-thirds the size of Earth. Fortunately, the 8000-kilometrewide storm is raging on Saturn's south pole. It is the first storm seen in the solar system, other than on Earth, that has a well-defined wall of towering clouds ringing a dark eye.

\section{Mars probe calls time}

Maybe it decided enough was enough. Sent on a two-year mission 10 years ago, the Mars Global Surveyor worked valiantly overtime, sending back more information about Mars than all earlier missions combined. NASA lost contact with the probe on 5 November. Its last signal indicated that it had entered a "safe" mode and was awaiting instructions from Earth.

\section{Fatbuster failure}

An anti-obesity vaccine has been abandoned following disappointing results in humans. The vaccine, developed by Cytos Biotechnology of Zurich, Switzerland, was meant to stimulate production of antibodies that would mop up ghrelin, a gut hormone thought to stimulate appetite (see New Scientist, 21 May 2005, p 9).

\section{Red meat warning}

Daily consumption of red meat may double the risk of certain breast cancers, a study of 90,000 women aged 26 to 46 suggests. Researchers speculate that growth hormones given to cattle or chemicals added during meat processing could fuel hormoneresponsive cancers, which account for two-thirds of breast cancers (Archives of Internal Medicine, vol 166, p 2253).

\section{Flying towards extinction}

Birds around the world are heading for extinction because of global warming. A WWF report released last week says that birds most at risk are migratory, mountain, island, wetland, Arctic, Antarctic and seabirds. A ${ }^{\circ} \mathrm{C}$ warming over pre-industrial levels could render extinct 38 per cent of European species and 72 per cent in north-east Australia. 